\title{
New records for Glyphonycteris Thomas, 1896 (Chiroptera: Phyllostomidae) from Colombia
}

\author{
Darwin Manuel Morales-Martínez ${ }^{1,2^{*}}$ and Andrés Felipe Suárez-Castro ${ }^{1,2,3}$ \\ 1 Grupo de Mastozoología Universidad Nacional de Colombia, Facultad de Ciencias, Universidad Nacional de Colombia, Carrera 45 No $26-85$. \\ Bogotá, Colombia. \\ 2 Yoluka ONG, Fundación de Investigación en Biodiversidad y Conservación, Carrera 9ạ No 61-51 oficina 201, Bogotá, Colombia. \\ 3 Universidad Nacional de Colombia, Instituto de Ciencias Naturales, Grupo de Conservación y Manejo de vida Silvestre, Carrera 45 No $26-85$. \\ Bogotá, Colombia. \\ * Corresponding author. E-mail: dmmoralesm@unal.edu.co
}

\begin{abstract}
We present new records of bats for Colombia, including the first documented records of Glyphonycteris daviesi for the country, collected in the savanna ecosystems from the Orinoco Llanos, and a new record of $G$. silvestris from the interAndean valley of Magdalena River that confirms its presence in this region of the country.
\end{abstract}

DOI: $10.15560 / 10.3 .639$

Species of Glyphonycteris Thomas, 1896 are poorly known foliage gleaning insectivore bats that inhabit the lowland forests of Central and South America (Ochoa and Velazco 2008; Zortea et al. 2008a; b). These bats have been considered rare because there are few specimens deposited in collections, and they are seldom caught in mist nets (Clark and Racey 2003; Gregorin and Rossi 2005). Simmons and Voss (1998) revised taxa traditionally considered subgenera of Micronycteris (Micronycteris, Trinycteris, Neonycteris, Lampronycteris, and Glyphonycteris) and assigned full generic rank to Glyphonycteris based on characters including the absence of an interauricular band, the calcar shorter than hindfoot, the rostral and anteorbital regions of the skull inflated, the braincase with a dome-shaped form, the deep basisphenoid pits; the upper internal incisors with a chisel-shaped form, the canines small but slightly bigger than the incisors; the upper third premolar (P3) molariform, upper fourth premolar (P4) with accessory cuspulids and the lower trilobed incisors.

Three species of Glyphonycteris are currently recognized: G. behnii (Peters, 1865) distributed in the Bolivian and Brazilian savannah and the Peruvian Amazon (Zortea et al. 2008b); G. sylvestris (Thomas, 1896) distributed from the lowlands of Central America southward to northern South America, with additional isolated records from southeastern Brazil (Zortea et al. 2008a), and G. daviesi (Hill, 1964) distributed in Honduras, Costa Rica, Panama southward to northern South America and Bolivia (Williams and Genoways 2008). Glyphonycteris sylvestris is the smallest species in the genus (forearm length less than $44 \mathrm{~mm}$, and skull length shorter than 22 $\mathrm{mm}$ ) and has two pairs of upper premolars (William and Genoways 2008). According to Solari et al. (2013) there are three documented records within Colombia: Alberico et al. (2000) reported a specimen deposited in the Instituto de Ciencias Naturales (ICN) of Universidad Nacional de
Colombia (ICN 14952) from Hato Nuevo, Caserío Tabaco, La Guajira; Simmons (1996) listed three specimens deposited in the Field Museum of Natural History (FMNH) captured in Socorré, Alto Rio Sinú, Bolívar (FMNH 69408, 69409, 69410) and Montenegro and Romero-Ruiz (1999) mentioned one specimen captured in an undisturbed lowland tropical forest at Serranía de Chiribiquete, Caquetá (Figure 1), and deposited in the ICN (ICN 14592). Although Cuartas-Calle and Muñoz-Arango (2003) reported $G$. sylvestris from the Departament of Antioquia, and MuñozSaba (2010) reported one specimen from the Caribbean region in the Departament of Córdoba, Pueblo Nuevo (ICN 17239) Solari et al. (2013) did not include these records, proposing a distribution restricted to the Amazon region.

Glyphonycteris daviesi is the largest species of the genus (forearm length over $50 \mathrm{~mm}$ and greatest length of the skull over $25 \mathrm{~mm}$ ), and can be unambiguously distinguished by having one pair of upper incisors, and the crowns of the lower incisors anterior-posteriorly elongated and transversely narrow (Hill 1964). Although the potential distribution of $G$. daviesi includes the Colombian Amazon there was no confirmed records of this species for the country and its presence in other types of ecosystems is doubtful (Mantilla-Meluk et al. 2009).

We present the first records of $G$. daviesi from Colombia by adding two localities in an ecosystem distinct from the lowland tropical rainforest of the Amazon basin along with our analyses of specimens attributed to Colombian records of G. sylvestris. For G. daviesi, external measurements (mm) were taken from the individuals in the field, while for $G$. sylvestris they were obtained from labels. Measurements were taken according to Rodríguez-Posada and SánchezPalomino (2009) with digital callipers to the nearest $0.1 \mathrm{~mm}$ : total body length (TL), tail length (TV), hind foot length (HF), ear length (EAR), forearm length (FA), greatest length of the skull, excluding incisors (GLS), condyle-incisive length (CIL), condyle-basal length (CBL), 
zygomatic breadth (ZB), mastoid breadth (BM), braincase breadth (BBC), breadth across postorbital constriction (POC), length of maxillary toothrow (CM3), and breadth across molars (M3M3).

We confirmed the identity of one male specimen of $G$. sylvestris for the Department of Antioquia deposited in the Instituto de Ciencias Naturales of the Universidad Nacional de Colombia (ICN 13313) from San Luis, Corregimiento

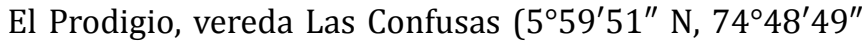
W). The specimen matches diagnostic characters for the species (Figure 2) having two pairs of upper premolars, and being a relatively small Glyphonycteris (FA $=39 \mathrm{~mm}$, $\mathrm{GLS}=18.8 \mathrm{~mm}$ ). All measurements of ICN 13313 fall within the range of size variation reported for specimens from French Guiana (Simmons and Voss 1998), from Brazil (Dias et al. 2003), and from Panama (Jones and Carter 1979; Table 1). San Luis is located in the eastern slope of the Cordillera Central, nested in the Magdalena River valley. The distribution of $G$. sylvestris for the Magdalena valley had been already reported by Simmons (1996;

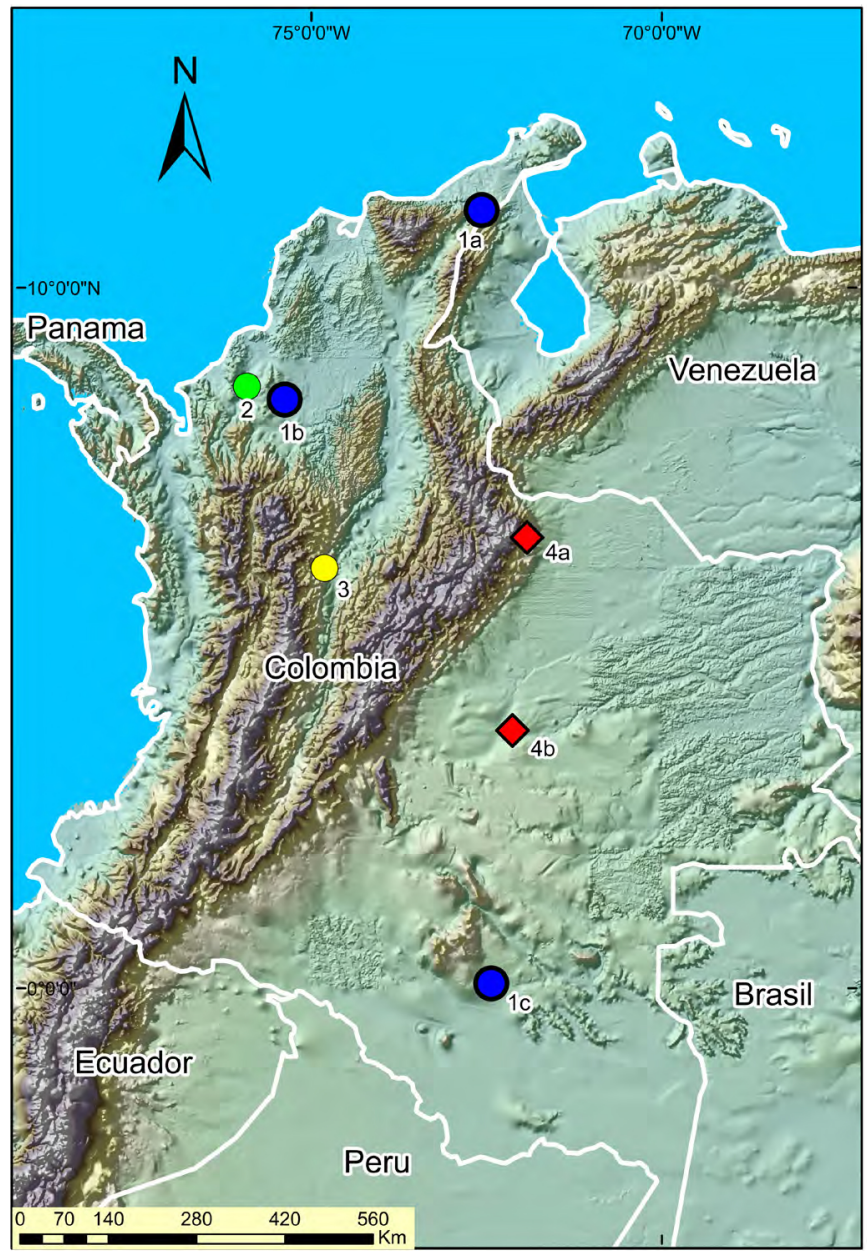

FIGURE 1. Localities reported to Glyphonycteris silvestris and G. daviesi from Colombia. Circles are specimens of G. sylvestris. 1. Missing specimens in mammal collection of Instituto de Ciencias Naturales (ICN): 1a. Alberico et al. (2000) Hato Nuevo, Caserío Tabaco, Department of La Guajira (ICN 14952); 1b. Muñoz-Saba (2010) Pueblo Nuevo, Departament of Córdoba (ICN 17239); 1c. Montenegro \& Romero-Ruiz (1999) Puerto Abeja, Serranía de Chiribiquete, Department of Caquetá (ICN 14592). 2. G. sylvestris with specimens deposited in museums documented by Simmons (1996): Socorré, Alto Rio Sinú, Department of Bolivar (FMNH $69408,69409,69410)$. 3. Confirmed voucher specimen of $G$. sylvestris from Colombia San Luis, Corregimiento El Prodigio, Vereda Las Confusas, Department of Antioquia (ICN 13313). Diamonds are new records of G. daviesi from Colombia: 4a. Tame, Department of Arauca (ICN 21552) and 4b. San Martín, Department of Meta.
FMNH 69408, 69409, 69410) and Alberico et al. (2000: fig. 1) but has not been included in the distributional range previously proposed by Zortea et al. (2008a), William and Genoways (2008) and Solari et al. (2013). On the other hand, we reviewed all material of Micronycterinae and Glyphonycterinae species (sensu Baker et al. 2003) deposited in the ICN collection, and did not find the specimens of $G$. sylvestris reported by Alberico et al. (2000), Muñoz-Saba (2010), or Montenegro and RomeroRuiz (1999). All the specimens were catalogued, but they are missing at the ICN and there are not records of loans to national or international collections.

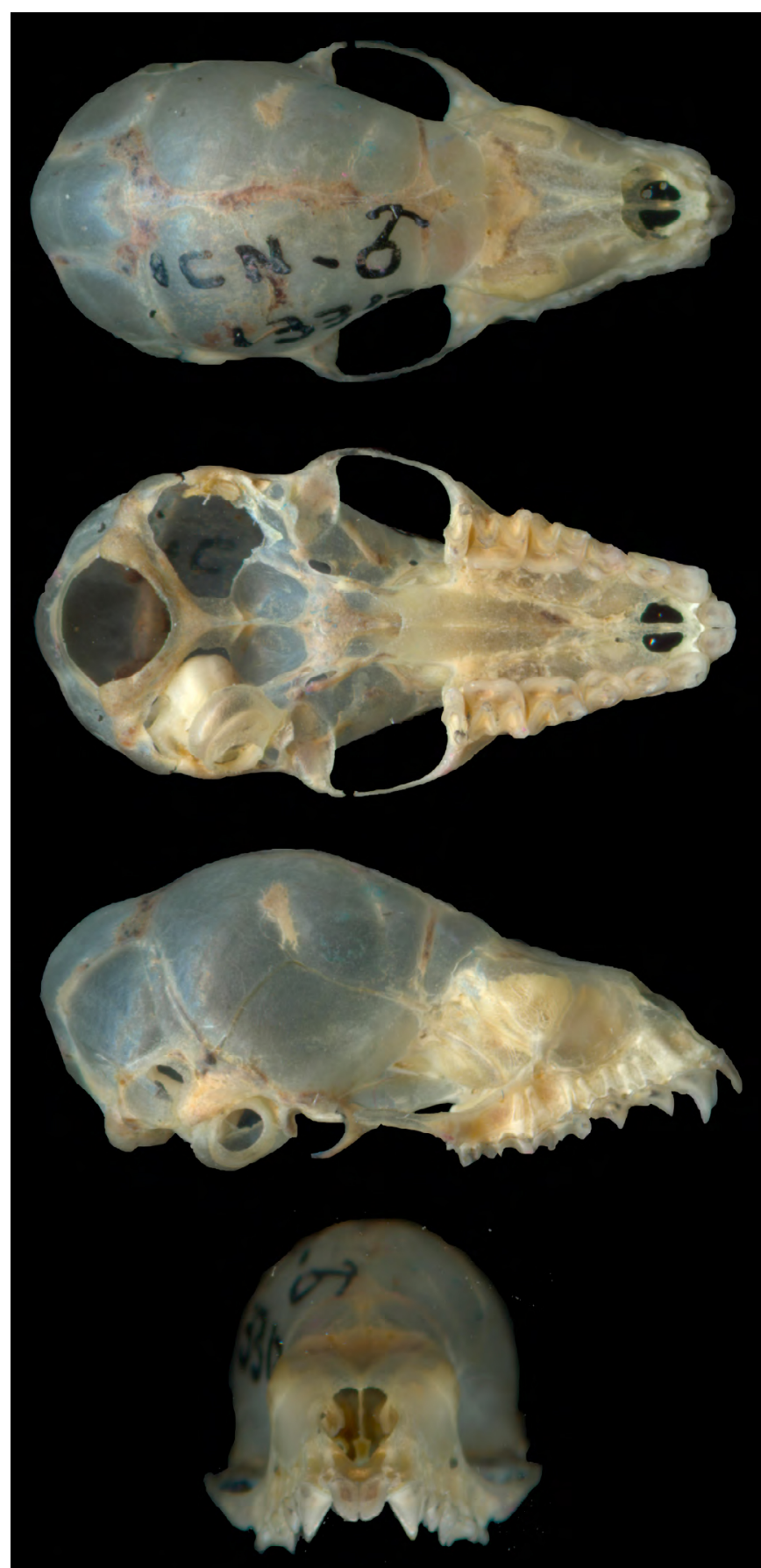

\section{$10 \mathrm{~mm}$}

FiguRE 2. Dorsal (upper), ventral (middle) and lateral (lower) view of the skull of Glyphonycteris sylvestris (ICN 13313), with detail of size and shape of the central upper incisors. 
We captured two individuals of $G$. daviesi in the Colombian Llanos region (Figure 1). Vegetation is dominated by extensive savannahs composed with grasslands and riparian forests. Bats were captured with ground-level mist nets ( $6 \mathrm{~m}$ in length; mesh $36 \mathrm{~mm}$ ). One specimen was captured during a mammal inventory in the municipality of Tame, Department of Arauca $\left(6^{\circ} 23^{\prime} 06.7^{\prime \prime}\right.$ $\mathrm{N}, 71^{\circ} 55^{\prime} 33.4^{\prime \prime} \mathrm{W}$; ICN 21552). The Tame specimen (ICN 21552) has all the diagnostic characters described for the species, including a large size for a Glyphonycteris $(\mathrm{FA}=55.1 \mathrm{~mm} ; \mathrm{GLS}=24.6 \mathrm{~mm})$, the presence of a single pair of upper incisors (Figure 3a) and the shape of the crowns of lower incisors, which are antero-posteriorly elongated and transversely narrow. Measurements are similar to those reported in previous studies from Guyana (Hill 1964), French Guiana (Simmons and Voss 1998), Venezuela (McCarthy and Ochoa 1991), Trinidad (Clark and Racey 2003), Panama (Jones and Carter 1979) and Brazil (Jones and Carter 1979; Gregorin and Rossi 2005; Table 2). Another individual of $G$. daviesi, an adult male, was captured during a mammal inventory in the Ecopetrol S.A. CP011 concession block in the municipality of San Martín, Department of Meta $\left(3^{\circ} 40^{\prime} 47.0^{\prime \prime} \mathrm{N}, 72^{\circ} 30^{\prime} 43.1^{\prime \prime}\right.$ W). This individual escaped by chewing through the cotton bag he had been placed after capture, as reported for others individuals by Williams and Genoways (2008). Despite this, the bat was identified by FA measuring $53 \mathrm{~mm}$ and canine-form incisors with the same size of canines. Furthermore the individual was previously photographed and unambiguously identified based on external characters (Figure 3B-C). The vegetation in Tame is dominated by flooded savannahs adjacent to riparian forest and palm swamps (Figure 4A), in contrast, San Martin gallery forests and palm swamps are situated in a matrix of high plain savannas (Figure 4B-C).

Regions and ecosystems here reported are novelties for the distribution of species of Glyphonycteris within
Colombia. This is relevant also because all Glyphonycteris individuals we studied were captured in areas that are or will be under strong anthropogenic pressure, mostly due to large mining projects that could cause a strong impact on ecosystems and biodiversity loss in a short term (Hooper et al. 2005). Although historically cattle ranching have been the principal economic activity in the area where the individuals of $G$. daviesi were captured, recently

TABLE 1. External and cranial measurements of the specimen of Glyphonycteris silvestris reported in this paper (ICN 13313), compared to the specimens reported by Simmons and Voss (1998) from French Guiana, Dias et al. (2003) from Brazil, and Jones and Carter (1979) from Panama. Measurements abbreviations are explained in the text. Collection abbreviations in the table: ALP: Collections of Adriano Lúcio Peracchi deposited in the Instituto de Biologia da Universidade Federal Rural do Rio do Janeiro; AMNH: American Museum of Natural History; ICN: Instituto de Ciencias Naturales Universidad Nacional de Colombia; USNM: National Museum of Natural History.

\begin{tabular}{|c|c|c|c|c|}
\hline & BRAZIL & $\begin{array}{l}\text { FRENCH } \\
\text { GUIANA }\end{array}$ & PANAMA & COLOMBIA \\
\hline $\begin{array}{l}\text { Collection } \\
\text { number }\end{array}$ & $\begin{array}{l}\text { ALP } \\
5856\end{array}$ & AMNH 267897 & $\begin{array}{c}\text { USNM } \\
396399\end{array}$ & ICN 13313 \\
\hline Sex & Male & Female & Female & Male \\
\hline Weight (g) & 7 & - & - & 8 \\
\hline $\mathrm{TL}$ & 57 & - & - & 65 \\
\hline TV & 9 & - & - & 9 \\
\hline $\mathrm{HF}$ & 12 & - & - & 12 \\
\hline EAR & 22 & - & - & 17 \\
\hline FA & 38.7 & 41.1 & 42 & 39 \\
\hline GLS & - & 20.2 & 19.8 & 18.8 \\
\hline CIL & - & - & - & 17.3 \\
\hline CBL & - & 18,5 & - & - \\
\hline ZB & - & 10.0 & 10.7 & 9.6 \\
\hline BM & - & 9.0 & - & 8.5 \\
\hline $\mathrm{BBC}$ & - & 8.4 & 8.7 & 8.2 \\
\hline POC & - & 4.7 & 4.5 & 4.6 \\
\hline CM3 & - & 8.1 & 7.9 & 7.7 \\
\hline M3M3 & - & 6.5 & 7.2 & 6.2 \\
\hline
\end{tabular}

TABLE 2. External and cranial measurements of the specimen of Glyphonycteris daviesi reported here (ICN 21552), compared to the specimens reported by Hill (1964) from Guyana, Jones and Carter (1979) from Panama, McCarthy and Ochoa (1991) from Venezuela, Simmons and Voss (1998) from French Guiana, Clark and Racey (2003) from Trinidad, and Gregorin and Rossi (2005) and Jones and Carter (1979) from Brazil. Measurements abbreviations are explained in the text. Collection abbreviations in the table: AMNH: American Museum of Natural History; BMNH: British Museum of Natural History; EBRG: Museo de la estación Biológica Rancho Grande; ICN: Instituto de Ciencias Naturales Universidad Nacional de Colombia; MNHN: Muséum National d'Histoire Naturelle; MZUSP: Museu de Zoologia da Universidade de São Paulo; USNM: National Museum of Natural History; UWI: Zoology Museum, University of West Indies.

\begin{tabular}{|c|c|c|c|c|c|c|c|c|c|}
\hline \multirow[b]{2}{*}{$\begin{array}{l}\text { Collection } \\
\text { number }\end{array}$} & \multirow{2}{*}{$\begin{array}{l}\text { TRINIDAD } \\
\text { UWI } 02.07\end{array}$} & \multicolumn{2}{|c|}{ FRENCH GUIANA } & \multirow{2}{*}{$\begin{array}{c}\text { GUYANA } \\
\text { BMNH } \\
64.767\end{array}$} & \multirow{2}{*}{$\begin{array}{c}\text { VENEZUELA } \\
\text { EBRG 15926; } \\
17029\end{array}$} & \multicolumn{2}{|c|}{ BRAZIL } & \multirow{2}{*}{$\begin{array}{c}\text { PANAMA } \\
\text { USNM } \\
335104\end{array}$} & \multirow{2}{*}{$\begin{array}{c}\text { COLOMBIA } \\
\text { ICN } 21552\end{array}$} \\
\hline & & $\begin{array}{c}\text { AMNH } \\
267856\end{array}$ & $\begin{array}{c}\text { MNHN } \\
1995.1029\end{array}$ & & & $\begin{array}{c}\text { MZUSP 29756; } \\
29760\end{array}$ & $\begin{array}{c}\text { USNM } \\
460089\end{array}$ & & \\
\hline Sex & Female & Male & Female & Female & 2 Males & 2 Females & Male & Male & Male \\
\hline Weight (g) & 22 & 17 & 20 & - & 20,23 & 24,25 & - & - & 18 \\
\hline $\mathrm{TL}$ & 83 & 80 & 83 & 79 & - & - & - & - & 71 \\
\hline TV & 8 & 10 & 10 & 10 & - & 5,6 & - & - & 5 \\
\hline EAR & 27 & 27 & 28 & 17 & - & $26,-$ & - & - & 24 \\
\hline $\mathrm{FA}$ & 56.7 & 52.5 & 57.0 & 57.1 & $53.6,54.0$ & $56.2,58.1$ & 54.7 & 54 & 55.1 \\
\hline GLS & 24.36 & - & 24.6 & 27.3 & $26.3,26.1$ & $27.0,27.4$ & ,26.1 & 27.3 & 24.6 \\
\hline CIL & 25.32 & - & 24.6 & 24.7 & $25.2,24.9$ & $24.9,25.6$ & - & - & 23.4 \\
\hline ZB & 12.68 & - & 12.7 & 13.3 & $11.5,11.2$ & $14.0,13.9$ & 12.8 & 12.8 & 12.9 \\
\hline BM & - & - & 10.9 & - & $10.7,10.8$ & - & - & - & 10.6 \\
\hline CM3 & 11.7 & - & 10.3 & 11.1 & $10.5,10.7$ & $10.9,11.0$ & 10.5 & 10.5 & 10.2 \\
\hline M3M3 & 9.2 & - & 8.9 & 9.3 & $8.5,9.0$ & $9.3,9.6$ & 9.1 & 9.1 & 8.8 \\
\hline
\end{tabular}



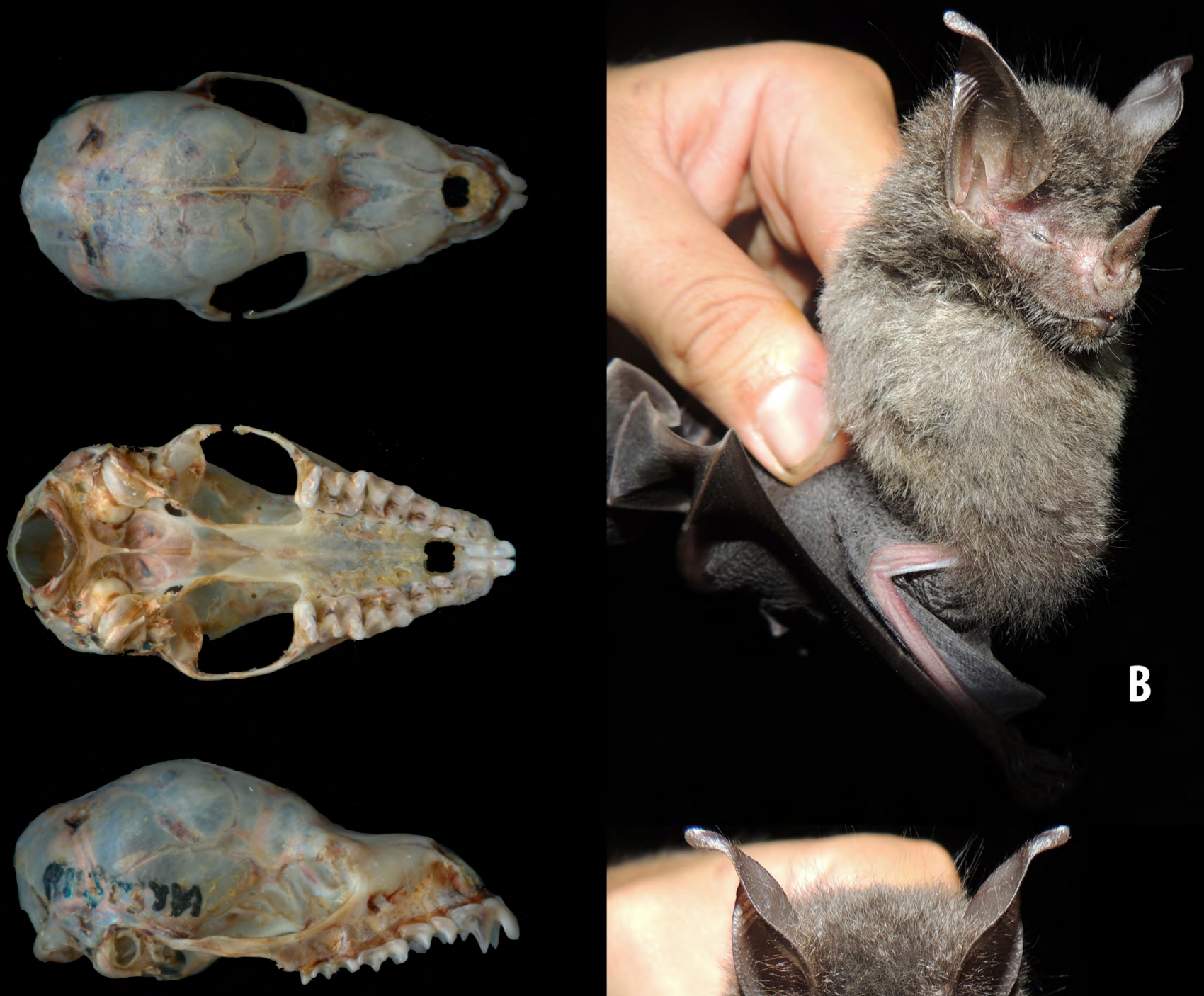

A

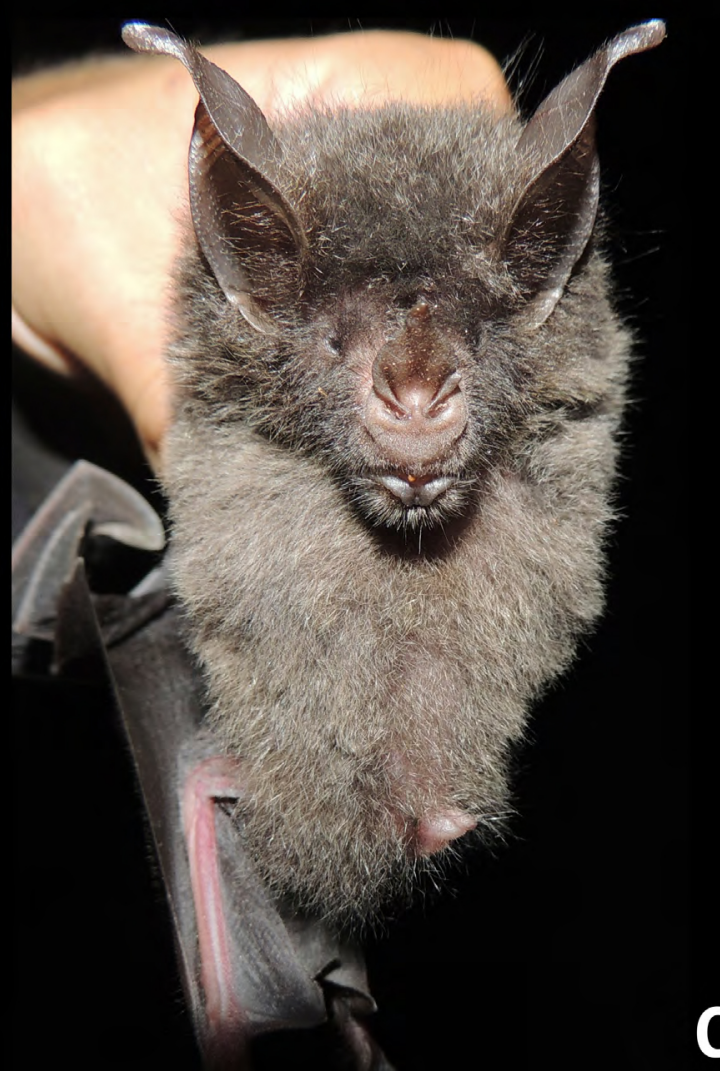

FigURE 3. A. Dorsal, ventral and lateral view of the skull of G. daviesi (ICN 21552), with detail of the size and shape of the central upper incisors. B and C: individual of G. daviesi captured at San Martin, Department of Meta. 
other activities such as oil extraction and rice crops have prompted high rates of natural habitat transformation (Andrade-C. 2011). Recent fauna assessments in Colombian Llanos have also registered new records to these areas (Suárez-Castro et al. 2012) demonstrating that there is a lack of knowledge about local faunal diversity and the necessity to develop intensive inventories and monitoring assessment programs in the area.

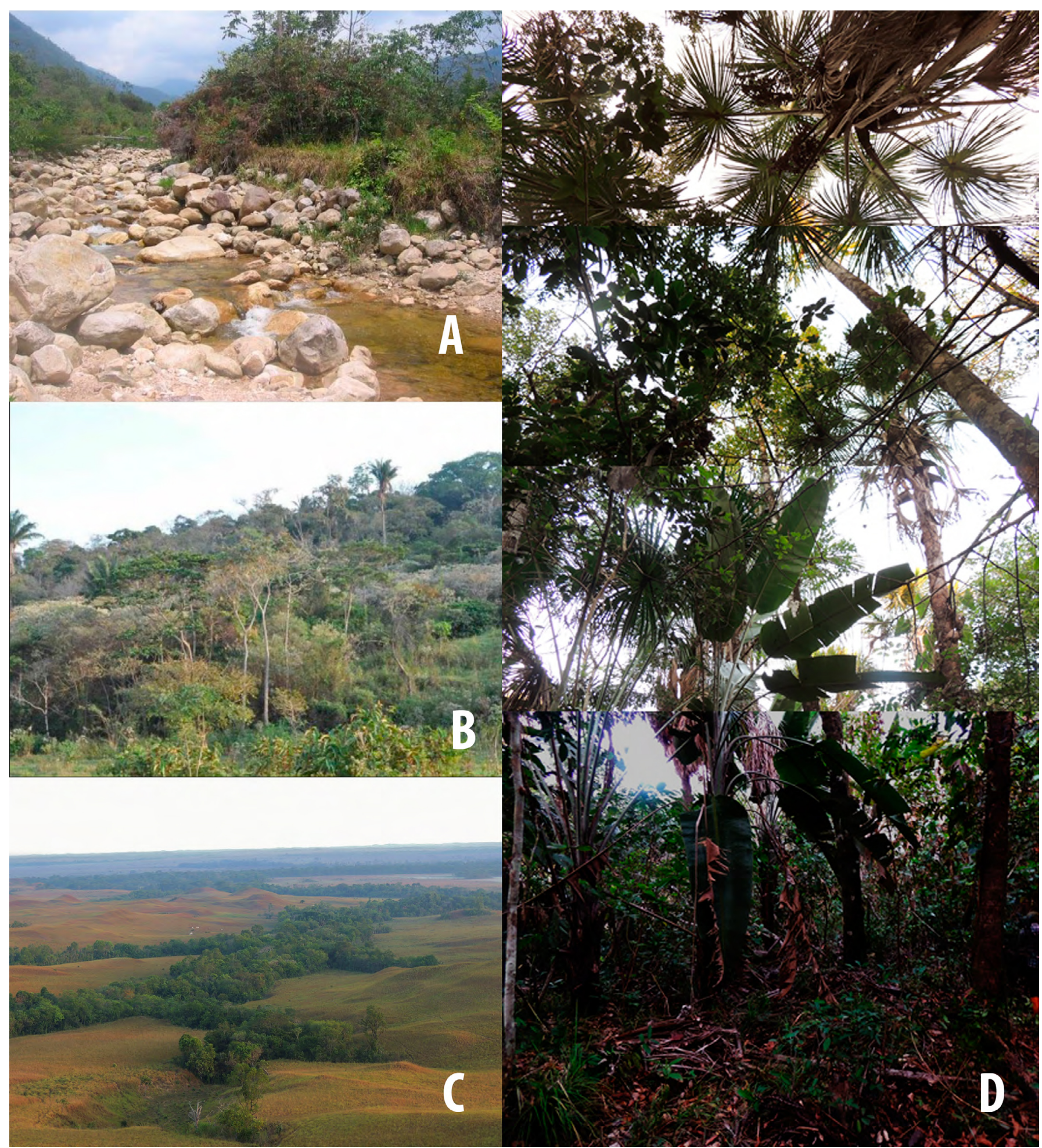

FIGURE 4. Locality records of Glyphonycteris daviesi in the Orinoco region, Colombia: a) general landscape of Tame showing flooded savannahs and riparian forests; b) forest fragment in Tame; c) general landscape of San Martín showing high plains savannahs and gallery forests; and d) general physiognomy of the palm swamp in San Martin.

ACKNowledgments: The individual photographed in the San Martin Llanos region was captured during an Environmental Impact Assessment project developed by Ecopetrol S.A. in the CPO11 concession block during February 2012. The Tame record was obtained during the project "Planeación Ambiental para la Conservación de la Biodiversidad en las Áreas Operativas de Ecopetrol - Ventana Tame-Arauca" by Yoluka ONG, Fundación de Investigación en Biodiversidad y Conservación. We thank Nodier Vivas-Zamora for collecting the specimen ICN 21252. We are grateful to Hugo Fernando López-Arévalo (ICN) for allowing us to study material under his care. We also thank to F. Forero (Humboldt Institute), Teddy Angarita-Sierra (Yoluka ONG) and H. García-Martínez (Humboldt Institute), coordinators of the Ecopetrol-Yoluka project. We also thank Miguel Rodríguez-Posada for his support in the elaboration of an earlier version of this paper. H. Ramirez-Chaves and B. K. Lim made valuable suggestions that helped to improve the manuscript. 


\section{LITERATURE CITED}

Andrade-C., M.G. 2011. Estado del conocimiento de la biodiversidad en Colombia y sus amenazas. Consideraciones para fortalecer la interacción ciencia-política. Revista de la Academia Colombiana de Ciencias Exactas Físicas y Naturales 35(137): 491-507 (http:// accefyn.org.co/revista/Vol_35/137/492-508.pdf).

Baker, R.J., S.R. Hoofer, C.A. Porter and R.A. Van Den Bussche. 2003. Diversification among New World Leaf-Nosed Bats: an evolutionary hypothesis and classification inferred from digenomic congruence of DNA sequence. Occasional Papers, Museum of Texas Tech University 230: 1-32 (http://www.nsrl.ttu.edu/publications/opapers/ops/ op230.pdf).

Clarke, F.M. and P.A. Racey. 2003. Discovery of the Bartica Bat Glyphonycteris daviesi (Chiroptera: Phyllostomidae) in Trinidad, West Indies. Acta Chiropterologica 5(1): 151-154.

Cuartas-Calle, C.A. and J. Muñoz-Arango. 2003. Lista de los mamíferos (Mammalia:Theria) del departamento de Antioquia.Biota Colombiana 4(1): 65-78 (http://www.redalyc.org/pdf/491/49140104.pdf). Dias, D., S.S. Pereira-Da Silva and A.L. Peracchi. 2003. Ocorrência de Glyphonycteris sylvestris Thomas (Chiroptera, Phyllostomidae) no Estado do Rio de Janeiro, sudeste do Brasil. Revista Brasileira de Zoologia 20(2): 365-366 (http://www.scielo.br/pdf/rbzool/v20n2/ v20n2a30.pdf).

Gregorin, R. and R. Rossi. 2005. Glyphonycteris daviesi (Hill, 164), a rare Central American and Amazonian bat recorded for Eastern Brazilian Atlantic Forest (Chiroptera, Phyllostomidae). Mammalia 69(3-4): 427-430 (doi: 10.1515/mamm.2005.035).

Hill, J.E. 1964. Notes on bats from British Guiana, with the description of a new genus and species of Phyllostomidae. Mammalia 28(4): 553-572.

Jones, J.K. and D.C. Carter. 1976. Annotated checklist, with keys to subfamilies and genera; pp. 7-38, in: R.J. Baker, J.K. Jones, Jr., D.C. Carter (eds.). Biology of bats of the New World family Phyllostomatidae. Part I. Lubbock, Texas: Tech University Press.

McCarthy, T.J. and J. Ochoa G. 1991. The presence of Centronycteris maximiliani and Micronycteris daviesi (Chiroptera) in Venezuela. The Texas Journal of Science 43(3): 332-334.

Muñoz-Saba, Y. 2010. Diversidad de Mamíferos en áreas del departamento de Córdoba, Colombia; pp. 381-398, in: J.O. Rangel-Ch (ed.). Colombia diversidad biótica IX. Ciénagas de Córdoba: Biodiversidad, Ecología y Manejo Ambiental. Bogotá: Instituto de Ciencias Naturales.

Ochoa, J. and P. Velazco. 2008. Glyphonycteris daviesi; in: IUCN 2013. IUCN Red List of Threatened Species. Version 2013.2. Eletronic Database accessible at http://www.iucnredlist.org/. Captured on 15 January 2014.
Rodríguez-Posada M.E. and P. Sánchez-Palomino. 2009. Taxonomía del género Phyllostomus (Chiroptera: Phyllostomidae) en Colombia. Mastozoología Neotropical 16(1): 153-168 (http://www.scielo.org. ar/pdf/mznt/v16n1/v16n1a13.pdf).

Sarmiento, G. 1994. Sabanas naturales: génesis y ecología; pp. 17-55, in: J.I. Hernández, G. Sarmiento G, J.M. Renjifo, D. Samper, H. Sánchez, M.E. Romero (eds.). Sabanas Naturales de Colombia. Cali, Colombia: Banco de Occidente.

Simmons, N.B. 1996. A new species of Micronycteris (Chiroptera: Phyllostomidae) from northeastern Brazil, with comments on phylogenetic relationships. American Museum Novitates 3158: 1-34 (http://hdl.handle.net/2246/3679).

Simmons, N.B. and R.S. Voss. 1998. The mammals of Paracou, French Guiana: A Neotropical lowland rainforest fauna. Part 1. Bats. Bulletin of the American Museum of Natural History 237: 1-219.

SolariS., Y.Muñoz-Saba,J.V.Rodríguez-Mahecha,T.R. Defler,H.E.RamírezChaves and F. Trujillo. 2013. Riqueza, endemismo y conservación de los mamíferos de Colombia. Mastozoología Neotropical 20(2): 301-365 (http://www.sarem.org.ar/wp-content/uploads/2013/ 12/SAREM_MastNeotrop_20-2_08_Solari.pdf).

Suárez-Castro, A.F., H. Ramírez-Chaves, M.E. Rodríguez-Posada and J. García. 2012. New records of Peropteryx leucoptera and first record of Peropteryx pallidoptera (Chiroptera-Emballonuridae) from Colombia. Mastozoología Neotropical 19(1): 165-171 (http://www. checklist.org.br/getpdf?NGD088-10)

Tuttle, M.D. 1970. Distribution and zoogeography of Peruvian bats, with comments on natural history. University of Kansas Science Bulletin. 49(1-8): 45-86.

Williams, S.L., and H. H. Genoways. 2008. Subfamily Phyllostominae Gray, 1825; pp. 255-300, in: A.L. Gardner (ed.). Mammals of South America, Vol. 1: Marsupials, Xenarthrans, Shrews, and Bats. Chicago: University of Chicago Press.

Zortea, M., E. Sampaio, B. Lim, S. Peters and J. Arroyo-Cabrales. 2008a. Glyphonycteris sylvestris; in: IUCN 2013. IUCN Red List of Threatened Species. Version 2013.2. Eletronic Database accessible at http:// www.iucnredlist.org/. Captured on 15 January 2014.

Zortea, M., Sampaio, E., Lim, B. and S. Peters. 2008b.Glyphonycteris behnii; in: IUCN 2013. IUCN Red List of Threatened Species. Version 2013.2. Eletronic Database accessible at http://www.iucnredlist.org/. Captured on 15 January 2014.

RECEIVED: March 2014

ACCEPTED: June 2014

Published OnLINE: July 2014

EDITORIAL RESPONSIBILITY: Valeria da Cunha Tavares 


\title{
New records for Glyphonycteris Thomas, 1896 (Chiroptera: Phyllostomidae) from Colombia
}

\author{
Darwin Manuel Morales-Martínez ${ }^{1,2^{*}}$ and Andrés Felipe Suárez-Castro ${ }^{1,2,3}$ \\ 1 Grupo de Mastozoología Universidad Nacional de Colombia, Facultad de Ciencias, Universidad Nacional de Colombia, Carrera 45 No $26-85$. \\ Bogotá, Colombia. \\ 2 Yoluka ONG, Fundación de Investigación en Biodiversidad y Conservación, Carrera 9a \# 61-51 oficina 201, Bogotá, Colombia. \\ 3 Universidad Nacional de Colombia, Instituto de Ciencias Naturales, Grupo de Conservación y Manejo de vida Silvestre, Carrera 45 No $26-85$ \\ Bogotá, Colombia \\ * Corresponding author. E-mail: dmmoralesm@unal.edu.co
}

\section{ERRATUM}

DOI: $10.15560 / 10.3 .639$

On pages 639 (left column), 640 (right column), and 641 (left column), William and Genoways 2008 should be read as Williams and Genoways 2008.

On page 641, right column, Hooper et al. 2005 was mistakenly cited, and should be replaced with Andrade-C. 2011.

The complete reference to Montenegro and RomeroRuiz (1999) was not included in the Literature Cited. It should be added as follows:
Montenegro, O.L. and M. Romero-Ruiz. 1999. Murciélagos del sector sur de la serranía de Chiribiquete, Caquetá, Colombia. Revista de la Academia Colombiana de Ciencias Exactas, Físicas y Naturales 23(Special Suppl.): 641-649.

The authors regret these errors.

JULY 2014 